\title{
Article \\ Incidence and Risk Factors of Reinfection with HCV after Treatment in People Living with HIV
}

\author{
Chien-Yu Cheng ${ }^{1,2} \oplus$, Shin-Yen Ku ${ }^{3}$, Yi-Chun Lin ${ }^{1}$, Cheng-Pin Chen ${ }^{1,4}{ }^{\oplus}$, Shu-Hsing Cheng ${ }^{1,5}$ and I-Feng Lin ${ }^{2, *}$ \\ 1 Department of Infectious Diseases, Taoyuan General Hospital, Ministry of Health and Welfare, \\ Taoyuan City 330, Taiwan; s841060@yahoo.com (C.-Y.C.); jean640514@gmail.com (Y.-C.L.); \\ jangbin@gmail.com (C.-P.C.); shuhsingcheng@gmail.com (S.-H.C.) \\ 2 Institute of Public Health, School of Medicine, National Yang-Ming Chiao Tung University, \\ Taipei City 112, Taiwan \\ 3 Department of Nursing, Taoyuan General Hospital, Ministry of Health and Welfare, Taoyuan City 330, Taiwan; \\ yen376@gmail.com \\ 4 School of Clinical Medicine, National Yang-Ming Chiao Tung University, Taipei City 112, Taiwan \\ 5 School of Public Health, Taipei Medical University, Taipei City 110, Taiwan \\ * Correspondence: iflin@nycu.edu.tw
}

Citation: Cheng, C.-Y.; Ku, S.-Y.; Lin, Y.-C.; Chen, C.-P.; Cheng, S.-H.; Lin, I.-F. Incidence and Risk Factors of Reinfection with HCV after Treatment in People Living with HIV. Viruses 2022, 14, 439. https:/ / doi.org/10.3390/v14020439

Academic Editors: Célia F. Rodrigues and Natália Cruz-Martins

Received: 28 December 2021

Accepted: 17 February 2022

Published: 21 February 2022

Publisher's Note: MDPI stays neutral with regard to jurisdictional claims in published maps and institutional affiliations.

Copyright: (C) 2022 by the authors. Licensee MDPI, Basel, Switzerland. This article is an open access article distributed under the terms and conditions of the Creative Commons Attribution (CC BY) license (https:// creativecommons.org/licenses/by/ $4.0 /)$.

\begin{abstract}
Infection with hepatitis $\mathrm{C}$ virus (HCV) does not induce protective immunity, and reexposure to $\mathrm{HCV}$ can reinfect the population engaging in high-risk behavior. An increasing incidence of acute hepatitis $\mathrm{C}$ infection in people living with HIV (PLWH) has been described in recent years. This retrospective cohort study was conducted in PLWH who completed HCV therapy between June 2009 and June 2020 at an HIV care hospital, to analyze their basic characteristics and risky behavior. Of 2419 patients, 639 were diagnosed with HCV infection and 516 completed the HCV therapy with a sustained virologic response. In total, 59 patients (11.4\%) were reinfected with acute hepatitis $C$, and the median time to reinfection was 85.3 weeks (IQR: 57-150). The incidence of reinfection was 6.7 cases /100 person-years. The factors associated with reinfection were being male (AHR, 8.02; 95\% CI 1.08-59.49), DAA (direct-acting antiviral) treatment (AHR, 2.23; 95\% CI 1.04-4.79), liver cirrhosis (AHR, 3.94; 95\% CI 1.09-14.22), heroin dependency (AHR: 7.41; 95\% CI 3.37-14.3), and HIV viral loads $<50$ copies $/ \mathrm{mL}$ at the follow-up (AHR: $0.47,95 \%$ CI 0.24-0.93) in the subgroup of people who inject drugs (PWID). Amphetamine abuse (AHR: 20.17; 95\% CI 2.36-172.52) was the dominant factor in the subgroup of men who have sex with men (MSM). Our study suggests that education and behavioral interventions are needed in this population to prevent reinfection.
\end{abstract}

Keywords: people who inject drugs (PWID); reinfection with HCV; people living with HIV (PLWH); heroin dependency; amphetamine abuse; men who have sex with men (MSM)

\section{Introduction}

An estimated 71 million people have chronic HCV infection, and a significant number of these people develop cirrhosis of the liver or liver cancer as a result [1]. Annually, 1.34 million deaths are caused by viral hepatitis, which is comparable to the deaths caused by tuberculosis and higher than those by HIV infection. HCV infection remains a major cause of liver-related morbidity and mortality among people living with HIV (PLWH), especially the people who inject drugs (PWID) [2,3]. The treatment uptake with interferonbased therapy has generally been high in the population of HIV-positive men who have sex with men (MSM), and high sustained virological response (SVR) rates have been reported, but there are relatively low SVR rates in the population of PWID [4]. Fortunately, oral direct antiviral agent (DAA)-based treatment trials have demonstrated very high efficacy (SVR > 95\%) among PLWH with HCV coinfection, even in the population of PWID [5,6]. Hence, some studies have predicted that scaling-up DAA treatment will substantially reduce the $\mathrm{HCV}$ prevalence $[7,8]$. 
An increasing incidence of $\mathrm{HCV}$ reinfection has been documented among MSM living with HIV in studies since 2010 [9-12]. A meta-analysis also reported that the overall HCV reinfection rate is high in PWID who continued their illicit drug use without opioid substitution therapy (OST) [13]. The most common risk factors for HCV infection included the sharing of needles for heroin injection and engaging in condomless anal intercourse with multiple sexual partners, though the interaction between behavioral factors and immunological factors associated with HCV reinfection is little known. Most existing research has put forward findings based on small sample sizes, a short duration of observation, and single-arm studies. In Europe, the duration of follow-up of studies after SVR ranges from four to eight years in general, and no such study has been conducted in Asia [14-16]. So, in this research, we assessed the incidence of HCV reinfection after a sustained virological response and examined the behavioral and immunological risk factors that played a role in affecting the outcomes in the observed cohort.

\section{Materials and Methods}

We conducted this observational cohort study at an HIV care hospital from June 2009 to June 2020. Briefly, people living with HIV who were diagnosed with acute or chronic $\mathrm{HCV}$ infection were included in the cohort, and clinical and virological data on their basic characteristics were retrospectively collected for both the primary HIV and their HCV infection. In Taiwan, face-to-face interviews assessing the patients' illicit drug abuse (such as heroin, amphetamines, and methadone) and risky sexual behavior were performed by HIV case managers when the patients returned for new rounds of their highly active anti-retroviral therapy every three months at outpatient clinics. If acute HCV infection was diagnosed during the follow-up, clinical covariates were taken as the closest measurements to the date of follow-up, including the CD4 lymphocyte count, HIV RNA viral load, HCV RNA viral load, HCV genotype, regimens of HCV treatment, and STDs, with risky behavior assumed in the past three months.

\subsection{Study Procedure}

Systemic screening for the HCV antibody was performed annually in all HIV-positive patients between 1 June 2009 and 31 December 2019. The HCV RNA was tested for inpatients who were positive for the HCV antibody, and treatment consisted of peginterferon alfa plus ribavirin (PegIFN/RBV), or DAAs with or without ribavirin. The HCV RNA was tested at the baseline before HCV therapy, at the end of treatment, at follow-up week 12 or 24 , and then at least once annually. A sustained virological response (SVR) was defined as one negative HCV RNA test 12 or 24 weeks after the end of treatment (depending on the treatment regimen). Patients were tested for the presence of HCV RNA every year at their physician's discretion, with additional testing if HCV reinfection was suspected.

The following covariates were included in the model: age, gender, risk factors for $\mathrm{HCV}$ and HIV infection, CD4 lymphocyte count, HIV RNA viral load before and after HCV therapy, HCV RNA viral load, HCV genotype, regimens of HCV therapy, risky behavior, STDs, HCV treatment year, and history of liver cirrhosis.

Demographic information on each patient's age, gender (male or female), and risk of HCV infection were obtained from their medical records, and their CD4 lymphocyte count, HIV RNA viral load, HCV RNA viral load, and HCV genotype were acquired from medical reports at the hospital. The HCV genotype was classified as either 1, 2, 3, 4, or 6, and a CD4 lymphocyte count above 500 cells $/ \mathrm{mL}$ was defined as adequate immunity. The HIV RNA was measured with COBAS AmpliPrep TaqMan HIV-1 test version 2.0 (Roche, Mannheim, Germany), with a lower limit of quantitation of fewer than 20 copies $/ \mathrm{mL}$. HIV RNA below 50 copies/mL was defined as an HIV status that was under control.

Information about risky behavior was obtained from HIV case managers' extensive counseling of patients during their follow-up every three months. Risky behavior included heroin dependency, methadone replacement therapy, amphetamine abuse, and multiple sexual partners. 


\subsection{Definition}

$\mathrm{HCV}$ reinfection was defined as a positive HCV RNA test, preceded by at least one negative HCV RNA test result after HCV treatment. The estimated date of reinfection was the date of the first positive test result after the end of treatment. Plasma HCV RNA viral loads were measured using a Roche LightCycler RNA Master SYBR Green I/High Pure Viral Nucleic Acid Kit (Roche, Mannheim, Germany) with a lower limit of quantitation of less than $10 \mathrm{IU} / \mathrm{mL}$. The HCV genotype was determined using an Abbott HCV Real-Time Genotype II assay (Abbott Diagnostics, Chicago, IL, USA).

\subsection{Incidence}

Follow-up began at the end of treatment and continued until the estimated date of HCV reinfection for those who had reinfection, or the last HIV follow-up and negative HCV RNA test for those who did not experience reinfection. Patients who completed their $\mathrm{HCV}$ treatment then became at risk of subsequent reinfection. The incidence rate (IR) of reinfection and its corresponding 95\% confidence interval (CI) were calculated using a person-time approach.

\subsection{Statistical Analysis}

Patients' baseline characteristics are presented using descriptive statistics: the mean \pm standard deviation or median \pm interquartile range for continuous variables, and the frequency (percentage) for categorical variables. Categorical data were analyzed using $\chi^{2}$ or Fisher's exact test, as appropriate, and continuous variables were compared using the MannWhitney $\mathrm{U}$ test. The $95 \% \mathrm{CI}$ of the hazard ratio was computed using a binomial distribution.

\subsection{Analysis and Cox Proportional Hazard Models}

The cumulative incidence of the first reinfection during follow-up was estimated using the Kaplan-Meier test. Univariate and multivariate Cox proportional hazard models were generated to evaluate the risk factors of reinfection. The assumption of proportional hazards was tested using Schoenfeld residuals test. Certain important variables $(p<0.1$ in $\chi^{2}$, Fisher's exact test, or univariate analysis) were selected for subsequent multivariate analysis. All analyses were two-tailed, and $p<0.05$ was considered statistically significant. All analyses were conducted using SPSS version 24.0.

\section{Results}

\subsection{Baseline Characteristics}

We identified 516 HIV-positive patients with a documented HCV infection cure between June 2009 and June 2020, as shown in Figure 1. The baseline characteristics of the participants are presented in Table 1 . The majority of the included patients were male $(78.9 \%)$ with a mean age of 42.0 years. The study population consisted mainly of PWID (78.9\%), followed by men who have sex with men (MSM, 20.3\%), and heterosexuals $(0.8 \%)$. Most of the patients $(98.4 \%)$ had received ART at the time of HCV therapy initiation, with a median CD4 count of 506 cells $/ \mathrm{mm}^{3}$ (IQR 369-692), and $89.7 \%$ had plasma HIV RNA $<50$ copies/mL. Before HCV therapy initiation, the median plasma HCV RNA load was $6.32 \log _{10} \mathrm{IU} / \mathrm{mL}$, and the dominant genotype was genotype $6(\mathrm{n}=176,34.1 \%)$ followed by $1 \mathrm{~b}(\mathrm{n}=117,22.7 \%), 1 \mathrm{a}(\mathrm{n}=101,9.6 \%), 2(\mathrm{n}=82,15.9 \%)$, and $3(\mathrm{n}=44,8.5 \%)$. A SVR following treatment with pegylated interferon with/without ribavirin was achieved in $129(25 \%)$ patients, while $387(75 \%)$ patients were treated with DAAs (Table 1). 


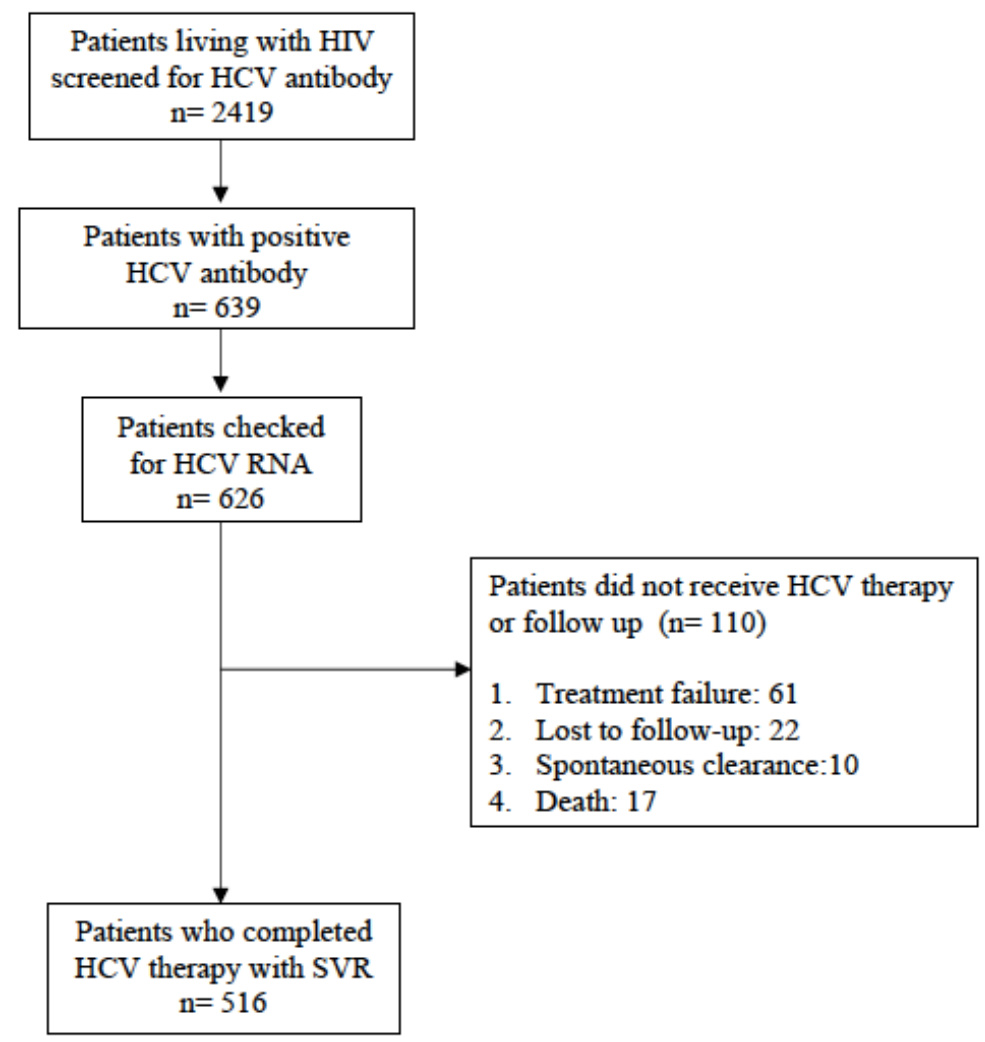

Figure 1. Flowchart of enrollment of study population since 2009.

Table 1. Characteristics of HIV-positive patients with or without hepatitis $\mathrm{C}$ virus $(\mathrm{HCV})$ reinfection at baseline.

\begin{tabular}{|c|c|c|c|c|}
\hline & $\begin{array}{c}\text { Total } \\
(n=516)\end{array}$ & $\begin{array}{l}\text { Reinfected } \\
(n=59)\end{array}$ & $\begin{array}{l}\text { Not Reinfected } \\
\quad(n=457)\end{array}$ & $p$ \\
\hline age, year, mean (SD) & $42(9)$ & $40.1(7.7)$ & $42.4(8.6)$ & 0.067 \\
\hline male, n (\%) & $407(78.9)$ & $58(98.3)$ & $349(76.4)$ & $<0.001$ \\
\hline PWID, n (\%) & $407(78.9)$ & $48(81.4)$ & $359(78.6)$ & 0.718 \\
\hline MSM, n (\%) & $105(20.3)$ & $11(18.6)$ & $94(20.6)$ & 0.571 \\
\hline CD4 count in HCV treatment, cells $/ \mu \mathrm{L}$, median (IQR) & $506(369-692)$ & $475(360-701)$ & $514(369-690)$ & 0.3 \\
\hline HIV viral loads $<50$ copies $/ \mathrm{mL}$ in HCV treatment, $\mathrm{n}(\%)$ & $463(89.7)$ & $49(83.1)$ & $414(90.6)$ & 0.073 \\
\hline HCV RNA before treatment, $\log _{10}$, median (IQR) & $6.32(5.5-6.8)$ & $6.37(5.1-6.9)$ & $6.32(5.6-6.8)$ & 0.908 \\
\hline \multicolumn{5}{|c|}{ HCV genotype } \\
\hline $1 \mathrm{a}, \mathrm{n}(\%)$ & $101(19.6)$ & $14(23.7)$ & $87(19.0)$ & 0.393 \\
\hline $1 b, n(\%)$ & $117(22.7)$ & $17(28.8)$ & $100(21.9)$ & 0.231 \\
\hline $2, \mathrm{n}(\%)$ & $82(15.9)$ & $9(15.3)$ & $73(16.0)$ & 0.887 \\
\hline $3, \mathrm{n}(\%)$ & $44(8.5)$ & $8(13.6)$ & $36(7.9)$ & 0.141 \\
\hline $6, \mathrm{n}(\%)$ & $176(34.1)$ & $11(18.6)$ & $165(36.1)$ & 0.008 \\
\hline HCV treatment & & & & $<0.001$ \\
\hline DAA (direct-acting antiviral), n (\%) & $387(75)$ & $27(45.8)$ & $360(78.8)$ & \\
\hline Peginterferon \pm ribavirin, $\mathrm{n}(\%)$ & $129(25)$ & $32(54.2)$ & $97(21.2)$ & \\
\hline HCV treatment year & & & & $<0.001$ \\
\hline 2010-2016, n (\%) & $106(21)$ & $29(49.2)$ & $77(16.8)$ & \\
\hline 2017-2019, n (\%) & $410(79)$ & $30(50.8)$ & $380(83.2)$ & \\
\hline Liver cirrhosis, $\mathrm{n}(\%)$ & $17(3.3)$ & $3(5.1)$ & $14(3.1)$ & 0.414 \\
\hline
\end{tabular}




\subsection{Immunological Status and Counseling Interview at Follow-Up}

Through extensive counseling, 167 patients (32.4\%) were found to have taken methadone replacement therapy, 142 (27.5\%) were heroin dependent, 71 (13.8\%) abused amphetamine, $38(7.4 \%)$ had multiple sexual partners, and $35(6.8 \%)$ were diagnosed with syphilis in the past three months. Finally, 59 of these patients $(11.4 \%)$ presented with an episode of acute $\mathrm{HCV}$ reinfection, and the median duration of HCV reinfection was 85.3 weeks (IQR 4.8-12.5). The median follow-up time for the 516 patients we included was 63.6 weeks (IQR 48.3-114.5), totaling 884.6 person-years. A total of 59 reinfections occurred, and the overall incidence rate of $\mathrm{HCV}$ reinfection was 6.7/100 person-years (Table 2).

Table 2. Counseling interview on risky behavior and immunological status at follow-up.

\begin{tabular}{|c|c|c|c|c|}
\hline & $\begin{array}{c}\text { Total } \\
(n=516)\end{array}$ & $\begin{array}{l}\text { Reinfected } \\
\quad(\mathrm{n}=59)\end{array}$ & $\begin{array}{l}\text { Not Reinfected } \\
\qquad(\mathrm{n}=457)\end{array}$ & $p$ \\
\hline Follow-up time after treatment, weeks, median (IQR) & $\begin{array}{c}63.6 \\
(48.3-114.5)\end{array}$ & $\begin{array}{c}85.3 \\
(57.0-150)\end{array}$ & $\begin{array}{c}62.4 \\
(47.6-106)\end{array}$ & 0.009 \\
\hline \multicolumn{5}{|l|}{ Risky behavior and disease } \\
\hline Heroin dependency, $\mathrm{n}(\%)$ & $142(27.5)$ & $39(66.1)$ & $103(22.5)$ & $<0.001$ \\
\hline Methadone replacement therapy, n (\%) & $167(32.4)$ & $23(39.0)$ & $144(31.5)$ & 0.248 \\
\hline Amphetamine abuse, $\mathrm{n}(\%)$ & $71(13.8)$ & $11(18.6)$ & $60(13.1)$ & 0.247 \\
\hline Multiple sexual partners, $\mathrm{n}(\%)$ & $38(7.4)$ & $10(16.9)$ & $28(6.1)$ & 0.003 \\
\hline Recent syphilis, n (\%) & $35(6.8)$ & $5(8.5)$ & $30(6.6)$ & 0.583 \\
\hline No risky behavior, $\mathrm{n}(\%)$ & $248(48.1)$ & $6(10.2)$ & $242(53.0)$ & $<0.001$ \\
\hline CD4 count at follow-up, cells / $\mu \mathrm{L}$, median (IQR) & $550(414-764)$ & $480(377-652)$ & $573(423-779)$ & 0.022 \\
\hline HIV viral loads $<50$ copies $/ \mathrm{mL}$ at follow-up, n (\%) & $466(90.3)$ & $47(79.7)$ & $419(91.7)$ & 0.003 \\
\hline
\end{tabular}

\subsection{Risk Factors of HCV Reinfection: Overall and Subgroup Analyses}

As shown in Table $3 \mathrm{HCV}$ reinfection was analyzed in Cox proportional hazards regression model, and the factors associated with reinfection were liver cirrhosis (AHR 3.61, 95\% CI 1.02-12.71), heroin dependency (AHR 9.35, 95\% CI 4.28-20.44), and multiple sexual partners (AHR 56.37, 95\% CI 6.12-519.53). In the subgroup of PWID (Table 4), being male (AHR, 8.02; 95\% CI 1.08-59.49), DAA (direct-acting antiviral) treatment (AHR, 2.23; 95\% CI 1.04-4.79), liver cirrhosis (AHR, 3.94; 95\% CI 1.09-14.22), and heroin dependency (AHR: 7.41, 95\% CI 3.37-14.3) were risk factors, while an HIV viral load $<50$ copies $/ \mathrm{mL}$ at the follow-up (AHR: $0.47,95 \%$ CI 0.24-0.93) was a protective factor against reinfection. Then, in the subgroup of MSM (Table 5), amphetamine abuse (AHR: 20.17, 95\% CI 2.36-172.52) was the only risk factor. 
Table 3. Risk factors and reported behavior at the end of the follow-up or at hepatitis C virus (HCV) reinfection in Cox proportional hazards regression model.

\begin{tabular}{|c|c|c|c|c|c|c|}
\hline & $\begin{array}{c}\text { Crude } \\
\text { Hazard Ratio }\end{array}$ & $95 \% \mathrm{CI}$ & $p$ & $\begin{array}{c}\text { Adjusted } \\
\text { Hazard Ratio }\end{array}$ & $95 \%$ CI & $p$ \\
\hline Male & 11.33 & $1.57-81.95$ & 0.016 & 6.7 & $0.91-49.39$ & 0.062 \\
\hline HCV genotype 6 & 0.69 & $0.35-1.33$ & 0.262 & 0.74 & $0.37-1.47$ & 0.387 \\
\hline DAA (direct-acting antiviral) & 0.61 & $0.31-1.19$ & 0.145 & 1.7 & $0.49-5.91$ & 0.401 \\
\hline Treatment year 2017 to 2019 & 0.57 & $0.29-1.14$ & 0.111 & 1.31 & $0.36-4.8$ & 0.68 \\
\hline Liver cirrhosis & 5.99 & $1.78-20.15$ & 0.004 & 3.61 & $1.02-12.71$ & 0.046 \\
\hline Heroin dependency & 4.32 & $2.51-7.44$ & $<0.001$ & 9.35 & $4.28-20.44$ & $<0.001$ \\
\hline Methadone replacement therapy & 0.72 & $0.43-1.22$ & 0.223 & 0.64 & $0.34-1.18$ & 0.151 \\
\hline Amphetamine abuse & 1.78 & $0.92-3.46$ & 0.088 & 0.16 & $0.02-1.61$ & 0.07 \\
\hline Multiple sexual partners & 3.5 & $1.75-7.00$ & $<0.001$ & 56.37 & $6.12-519.53$ & $<0.001$ \\
\hline Recent syphilis & 1.1 & $0.44-2.77$ & 0.836 & 1.11 & $0.38-3.31$ & 0.846 \\
\hline CD4 count $>500$ cells $/ \mu \mathrm{L}$ at follow-up & 1.92 & $1.14-3.22$ & 0.014 & 0.75 & $0.41-1.35$ & 0.33 \\
\hline $\begin{array}{c}\text { HIV viral load }<50 \text { copies } / \mathrm{mL} \text { at } \\
\text { follow-up }\end{array}$ & 0.59 & $0.31-1.11$ & 0.099 & 0.58 & $0.3-1.12$ & 0.104 \\
\hline
\end{tabular}

Table 4. Risk factors and reported behavior at the end of the follow-up or at hepatitis C virus (HCV) reinfection in the subgroup of PWID.

\begin{tabular}{|c|c|c|c|c|c|c|}
\hline & $\begin{array}{c}\text { Crude } \\
\text { Hazard Ratio }\end{array}$ & $95 \% \mathrm{CI}$ & $p$ & $\begin{array}{c}\text { Adjusted } \\
\text { Hazard Ratio }\end{array}$ & $95 \% \mathrm{CI}$ & $p$ \\
\hline Male & 12.14 & $1.67-88.09$ & 0.014 & 8.02 & $1.08-59.49$ & 0.042 \\
\hline HCV genotype 6 & 0.68 & $0.35-1.35$ & 0.272 & 0.78 & $0.39-1.55$ & 0.473 \\
\hline DAA (direct-acting antiviral) & 2.07 & $0.93-4.61$ & 0.073 & 2.23 & $1.04-4.79$ & 0.04 \\
\hline Liver cirrhosis & 6.62 & $1.92-22.92$ & 0.003 & 3.94 & $1.09-14.22$ & 0.037 \\
\hline Heroin dependency & 6.55 & $3.17-13.55$ & $<0.001$ & 7.41 & $3.37-16.3$ & $<0.001$ \\
\hline Methadone replacement therapy & 1.37 & $0.78-2.42$ & 0.276 & 0.62 & $0.34-1.14$ & 0.126 \\
\hline Amphetamine abuse & 0.30 & $0.04-2.15$ & 0.229 & 0.15 & $0.02-1.13$ & 0.066 \\
\hline CD4 count $>500$ cells $/ \mu \mathrm{L}$ at follow-up & 0.58 & $0.33-1.04$ & 0.068 & 0.93 & $0.5-1.74$ & 0.82 \\
\hline $\begin{array}{c}\text { HIV viral load }<50 \text { copies } / \mathrm{mL} \text { at } \\
\text { follow-up }\end{array}$ & 0.46 & $0.24-0.88$ & 0.019 & 0.47 & $0.24-0.93$ & 0.031 \\
\hline
\end{tabular}

Table 5. Risk factors and reported behavior at the end of the follow-up or at hepatitis C virus (HCV) reinfection in the subgroup of MSM.

\begin{tabular}{|c|c|c|c|c|c|c|}
\hline & $\begin{array}{c}\text { Crude } \\
\text { Hazard Ratio }\end{array}$ & $95 \% \mathrm{CI}$ & $p$ & $\begin{array}{c}\text { Adjusted } \\
\text { Hazard Ratio }\end{array}$ & $95 \%$ CI & $p$ \\
\hline Treatment year 2017 to 2019 & 1.07 & $0.26-4.47$ & 0.925 & 0.83 & $0.17-4.02$ & 0.813 \\
\hline Amphetamine abuse & 21.57 & $2.74-169.79$ & 0.004 & 20.17 & $2.36-172.52$ & 0.006 \\
\hline Recent syphilis & 1.31 & $0.39-4.41$ & 0.667 & 0.8 & $0.2-3.15$ & 0.749 \\
\hline CD4 count $>500$ cells $/ \mu \mathrm{L}$ at follow-up & 0.32 & $0.09-1.09$ & 0.067 & 0.66 & $0.14-3.1$ & 0.596 \\
\hline
\end{tabular}

Figure 2 shows the trends of HCV reinfection in the subgroups of PWID with or without heroin dependency and MSM with or without amphetamine abuse using KaplanMeier curves. 


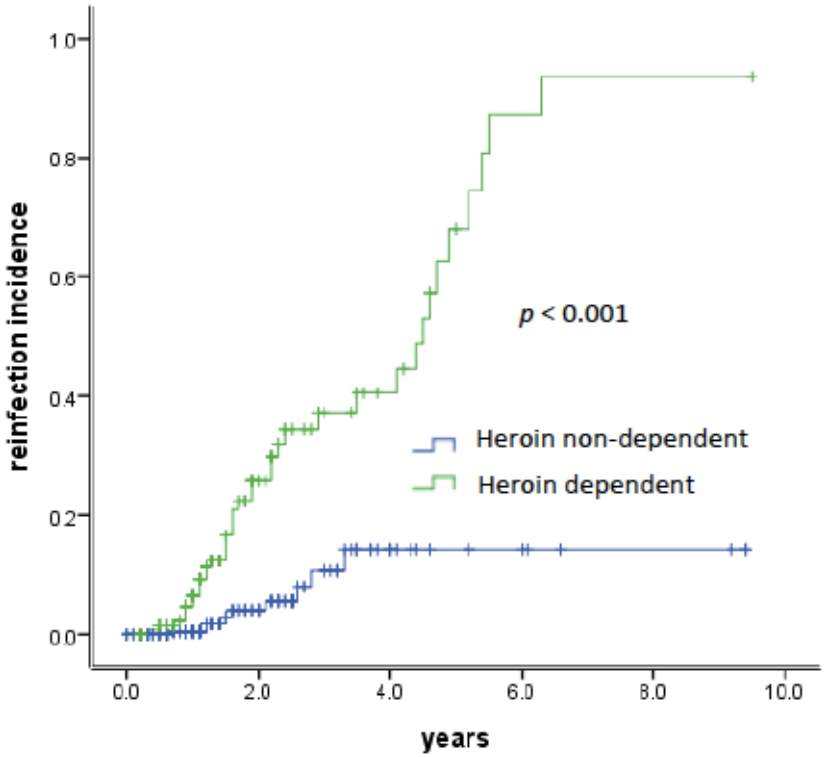

(a)

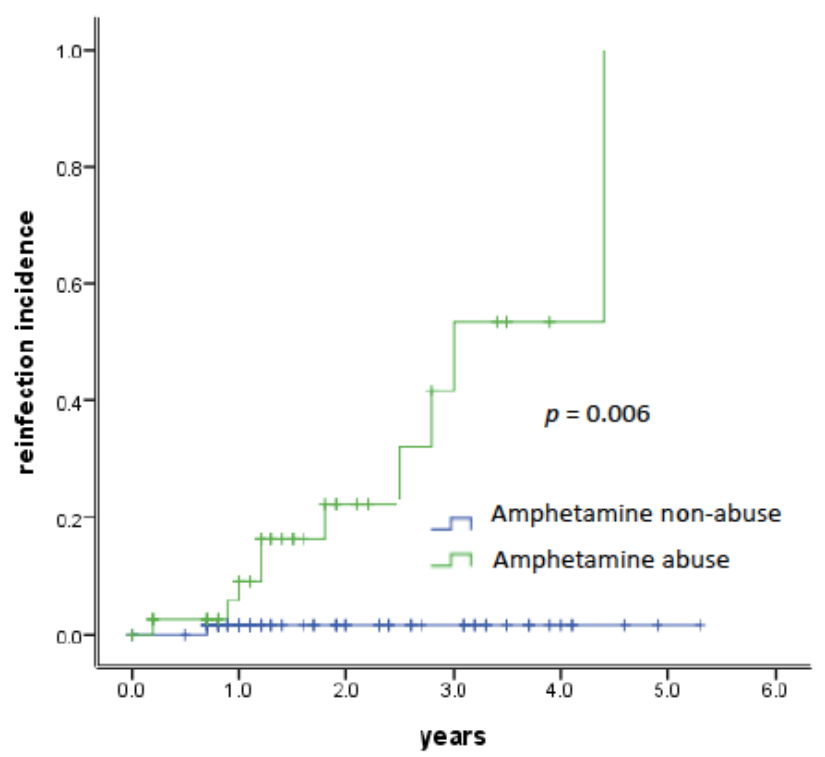

(b)

Figure 2. Incidence of HCV reinfection in subgroups of PWID (a) and MSM (b) with heroin dependency or amphetamine abuse by Kaplan-Meier curves.

\section{Discussion}

In this study of 516 PLWH with chronic or acute HCV infection, we assessed the incidence and risk factors of HCV reinfection among those who completed DAA or peginterferon treatment with an SVR. During a median follow-up of 1.2 years, we found an incidence of 6.7/100 person-years. In Cox proportional hazards regression model, the factors associated with $\mathrm{HCV}$ reinfection were being male, DAA treatment, liver cirrhosis, and heroin dependency in the subgroup of PWID, and amphetamine abuse was the dominant factor in the subgroup of MSM. To date, our observational cohort study spanning more than 10 years is the first, to our knowledge, that assesses behavioral risk factors for $\mathrm{HCV}$ reinfection in Asia.

In PWID, the incidence of HCV reinfection ranged between 0.8 and 33.0 per 100PY in the findings of different small studies or cohorts [17-20], and the pooled reinfection incidence in injected drug users after HCV SVR was 6.44 (95\% CI 2.49-16.69) per 100PY in a meta-analysis studied by Aspinall et al. [21]. The impact of ongoing injected drug use post-SVR or the end of HCV therapy was presented in further studies. Midgard et al. showed that the reinfection incidence rose to 5.8 per 100PY (95\% CI 3.0-10.2) among participants who reported injected drug use post-treatment, compared with those who abstained from injecting for more than six months (2.0 per 100PY (95\% CI 1.0-3.5)) [17]. Weir et al. also demonstrated that the incidence of reinfection was 5.7 per $100 \mathrm{PY}(95 \% \mathrm{CI}$ 1.8-13.3) among PWID who had been hospitalized for an opiate- or injection-related cause post-SVR, and the overall reinfection incidence was 1.7 per 100PY (95\% CI 0.7-3.5) among lifetime-long PWID following SVR in Scotland [22]. In our study, the adjusted hazard ratio of heroin dependency in PWID was 7.41 (95\% CI 3.37-14.3). Compared with those in the previous studies, our observational cohort study produced a similar result, but our data contributed toward countering the lack of information on Asian subjects.

Research beyond this has demonstrated how methadone replacement therapy can reduce the incidence of $\mathrm{HCV}$ reinfection in PWID. Hajarizadeh et al. found that the HCV reinfection risk following treatment was higher in people with recent drug use who were not receiving OST (6.6/100PY) than those receiving OST with (5.9/100PY) or without recent drug use (1.4/100PY) [13]. A meta-analysis study showed the pooled reinfection incidence was 2.4 per 100PY (95\% CI 0.9-6.1) in PWID, but the incidence increased up to 6.4 per 100PY (95\% CI 2.5-16.7) in heroin-dependent people who did not receive OST [21]. Our study 
showed a similar trend (AHR, 0.62; 95\% CI 0.34-1.14), but the result was not significant due to our potential underestimation of the number of heroin-dependent PWID receiving methadone replacement therapy.

Among PWID who completed HCV therapy with DAAs, our study showed a similar incidence of reinfection $(6.01 / 100 \mathrm{PY})$ to that of the C-EDGE COSTAR trial (DAA-based treatment), which identified 11 cases of reinfection after the end of treatment, with an incidence of 4.6 per 100PY (95\% CI 1.7-10.0) [22]. The first DAA treatment was launched in 2016 in Taiwan, and the scaling-up of easy and less-toxic DAA treatments led to substantial reductions in the $\mathrm{HCV}$ prevalence. However, this also brought about a high incidence of reinfection due to the convenient regimen and short treatment duration, compared with the treatment regimen of peginterferon in PWID who either have HIV (an incidence of 3.2 per 100PY) or do not (an incidence of 2.23 per 100PY) [23].

Liver cirrhosis was also a risk factor of reinfection in our study, with an incidence of 18.1/100PY noted (AHR, 3.94; 95\% CI 1.09-14.22), though we could not distinguish reinfection from relapse due to a lack of phylogenetic analysis of HCV strains. Nonetheless, Pawel et al. demonstrated significantly lower response rates in patients with liver cirrhosis in their research (odds ratio, 4.43; 95\% CI, 1.59-12.38) [24].

A high incidence of HCV reinfection in MSM living with HIV has also been reported in several European countries since 2011, with incidence rates ranging from 4.8 to 21.8 per $100 \mathrm{PY}[9,11,16,25]$, and our study showed an incidence of 5.8 per 100PY. In combination, having multiple sexual partners and abusing amphetamines might increase the risk of reinfection (AHR: 20.17; 95\% CI, 2.36-172.52). We found that all subjects who had multiple sexual partners abused amphetamines when they were diagnosed with HCV reinfection. The potential mode of transmission is anal intercourse with risk of blood-blood contact, and abuse of amphetamine was the prime factor to put men at high risk in this way of infection with HCV or other sexually transmitted infections [26].

Taiwan CDC published an HIV pre-exposure prophylaxis (PrEP) guideline and initiated a government-led PrEP pilot targeting 1000 at-risk individuals from November 2016 to August 2017 [27]. For this reason, the HCV treatment period was analyzed before and after 2017; however, we found that the incidence from 2010 to $2016(6.7 / 100 \mathrm{PY})$ was not significantly different from that from 2017 to 2019 (5.0/100PY; AHR, 0.83, 95\% CI 0.17-4.02). We speculated that a high treatment uptake and early diagnosis likely suppressed the reinfection rates in our study, regardless of the activity of the PrEP pilot.

There are some limitations to our study that we must note here before concluding. First, the retrospective and observational nature of the study may have meant we missed out on detailed patient information, and this could have limited the analysis of potential risks. Second, some patient accounts may have been affected by recall bias or they may have concealed detailed behavioral information, such as heroin abuse, needle sharing, injection of amphetamine, or a high number of sexual partners, which may have led us to underestimate the effect of risky behavior. Third, HCV RNA PCR testing was not carried out at standardized intervals; instead, this depended on the physician's decision or the patient's medical condition. The estimated date of reinfection was the day of the first positive test result, but the exact date might have been at any time between the last negative and first positive test results. Therefore, we may have underestimated the incidence of reinfection. Fourth, we could not distinguish reinfection from late relapse as we did not perform a phylogenetic analysis of the HCV strains. Finally, this single-center study may not be generalizable to other hospitals or countries given the patient differences of various demographics and clinical characteristics between one location and another.

\section{Conclusions}

In conclusion, our study revealed an incidence of HCV reinfection similar to that found in Europe, which was significantly associated with risky behaviors, including heroin dependency and amphetamine abuse. Hence, we propose a need for education and behavioral interventions to prevent reinfection in this population. 


\begin{abstract}
Author Contributions: Conceptualization, C.-Y.C. and I.-F.L.; methodology, I.-F.L.; software, C.-Y.C. and I.-F.L.; validation, S.-Y.K., C.-P.C. and Y.-C.L.; formal analysis, C.-Y.C. and I.-F.L.; investigation, C.-Y.C. and S.-H.C.; resources, C.-Y.C. and S.-H.C.; data curation, I.-F.L.; writing-original draft preparation, C.-Y.C.; writing—review and editing, I.-F.L.; visualization, I.-F.L.; supervision, I.-F.L.; project administration, C.-Y.C. All authors have read and agreed to the published version of the manuscript.
\end{abstract}

Funding: This research received no external funding.

Institutional Review Board Statement: The study was conducted according to the guidelines of the Declaration of Helsinki and approved by the Institutional Review Board (IRB) of Taoyuan General Hospital (TYGH108014).

Informed Consent Statement: Patient consent was waived due to the retrospective nature of the study and all data were analyzed without personal sensitive information.

Data Availability Statement: All data analyzed or generated during this study are included in the manuscript.

Conflicts of Interest: The authors declare no conflict of interest.

\title{
References
}

1. World Health Organization. Global Hepatitis Report; WHO: Geneva, Switzerland, 2017.

2. Ioannou, G.N.; Bryson, C.B.; Weiss, N.S.; Miller, R.; Scott, J.D.; Boyko, E.J. The prevalence of cirrhosis and hepatocellular carcinoma in patients with human immunodeficiency virus infection. Hepatology 2013, 57, 249-257. [CrossRef] [PubMed]

3. Rosenthal, E.; Roussillon, C.; Salmon-Céron, D.; Georget, A.; Hénard, S.; Huleux, T.; Gueit, I.; Mortier, E.; Costagliola, D.; Morlat, P.; et al. Liver-related deaths in HIV-infected patients between 1995 and 2010 in France: The Mortavic 2010 study in collaboration with the Agence Nationale de Recherche sur le SIDA (ANRS) EN 20 Mortalite 2010 survey. HIV Med. 2015, 16, 230-239. [CrossRef] [PubMed]

4. Chen, C.-P.; Cheng, C.-Y.; Zou, H.; Cheng, C.-H.; Cheng, S.-H.; Chen, C.-K.; Chen, C.-H.; Bair, M.-J. Evaluation of cost-effectiveness of peginterferon plus ribavirin for chronic hepatitis $C$ treatment and direct-acting antiviral agents among HIV-infected patients in prison and community settings. J. Microbiol. Immunol. Infect. 2019, 52, 556-562. [CrossRef] [PubMed]

5. Rockstroh, J.K.; Nelson, M.; Katlama, C.; Lalezari, J.; Mallolas, J.; Bloch, M.; Matthews, G.V.; Saag, M.S.; Zamor, P.J.; Orkin, C.; et al. Efficacy and safety of grazoprevir (MK-5172) and elbasvir (MK-8742) in patients with hepatitis C virus and HIV co-infection (C-EDGE CO-INFECTION): A nonrandomised, open-label trial. Lancet HIV 2015, 2, e319-e327. [CrossRef]

6. Wyles, D.L.; Ruane, P.J.; Sulkowski, M.S.; Dieterich, D.; Luetkemeyer, A.; Morgan, T.R.; Sherman, K.E.; Dretler, R.; Fishbein, D.; Gathe, J.C., Jr.; et al. Daclatasvir plus sofosbuvir for HCV in Patients coinfected with HIV-1. N. Engl. J. Med. 2015, 373, 714-725. [CrossRef]

7. Martin, N.K.; Thronton, A.; Hickman, M.; Sabin, C.; Nelson, M.; Cooke, G.S.; Maritn, T.C.S.; Delpech, V.; Ruf, M.; Price, H.; et al. Can hepatitis $\mathrm{C}$ virus (HCV) direct-acting antiviral treatment as prevention reverse the HCV epidemic among men who have sex with men in the United Kingdom? Epidemiological and modeling insights. Clin. Infect. Dis. 2016, 62, 1072-1080. [CrossRef] [PubMed]

8. Soctt, N.; Stoove, M.; Wilson, D.P.; Keiser, O.; El-Hayek, C.; Doyle, J.; Hellard, M. Eliminating hepatitis C virus as a public health threat among HIV-positive men who have sex with men: A multimodelling approach to understand differences in sexual risk behaviour. J. Int. AIDS Soc. 2018, 21, e25059. [CrossRef] [PubMed]

9. Hagan, H.; Jordan, A.E.; Neurer, J.; Cleland, C.M. Incidence of sexually-transmitted hepatitis C virus infection in HIV-positive men who have sex with men: A systematic review and meta-analysis. AIDS 2015, 29, 2335. [CrossRef] [PubMed]

10. van der Helm, J.; Prins, M.; del Amo, J.; Bucher, H.C.; Chene, G.; Dorrucci, M.; Gill, J.; Hamouda, O.; Sannes, M.; Porter, K.; et al. The hepatitis C epidemic among HIV-positive MSM: Incidence estimates from 1990 to 2007. AIDS 2011, 25, 1083-1091. [CrossRef] [PubMed]

11. Lambers, F.A.E.; Prins, M.; Thomas, X.; Molenkamp, R.; Kwa, D.; Brinkman, K.; van der Meer, J.T.M.; Schinkel, J.; MOSAIC (MSM Observational Study of Acute Infection with hepatitis C) study group. Alarming incidence of hepatitis C virus re-infection after treatment of sexually acquired acute hepatitis C virus infection in HIV-infected MSM. AIDS 2011, 25, F21-F27. [CrossRef] [PubMed]

12. Thomas, X.V.; Grady, B.P.X.; van der Meer, J.T.M.; Ho, C.K.; Vanhommerig, J.W.; Rebers, S.P.; De Jong, M.D.; van der Valk, M.; Prins, M.; Molenkamp, R.; et al. Genetic characterization of multiple hepatitis $C$ virus infections following acute infection in HIV-infected men who have sex with men. AIDS 2015, 29, 2287-2295. [CrossRef]

13. Hajarizadeh, B.; Cunningham, E.B.; Valerio, H.; Martinello, M.; Law, M.; Janjua, N.Z.; Midgard, H.; Dalgard, O.; Dillon, J.; Hickman, M.; et al. Hepatitis $C$ reinfection after successful antiviral treatment among people who inject drugs: A meta-analysis. J. Hepatol. 2020, 72, 643-657. [CrossRef] 
14. Swain, M.G.; Lai, M.-Y.; Shiffman, M.L.; Cooksley, W.G.E.; Zeuzem, S.; Dieterich, D.T.; Abergel, A.; Pessoa, M.G.; Lin, A.; Tietz, A.; et al. A sustained virologic response is durable in patients with chronic hepatitis $C$ treated with peginterferon alfa-2a and ribavirin. Gasteroenterology 2010, 139, 1593-1601. [CrossRef] [PubMed]

15. Marco, A.; Esteban, J.I.; Solé, C.; Silva, A.; Ortiz, J.; Roget, M.; Sarriera, C.; Teixidó, N.; Guerrero, R.A.; Caylà, J.A. Hepatitis C virus reinfection among prisoners with sustained virological response after treatment for chronic hepatitis C. J. Hepatol. 2013, 59, 45-51. [CrossRef]

16. Martin, T.C.; Martin, N.K.; Hickman, M.; Vickerman, P.; Page, E.E.; Everett, R.; Gazzard, B.G.; Nelson, M. Hepatitis C virus reinfection incidence and treatment outcome among HIV-positive MSM. AIDS 2013, 27, 2551-2557. [CrossRef] [PubMed]

17. Midgard, H.; Bjøro, B.; Mæland, A.; Konopski, Z.; Kileng, H.; Damås, J.K.; Paulsen, J.; Heggelund, L.; Sandvei, P.K.; Ringstad, J.O.; et al. Hepatitis C reinfection after sustained virological response. J. Hepatol. 2016, 64, 1020-1026. [CrossRef] [PubMed]

18. Weir, A.; McLeod, A.; Innes, H.; Valerio, H.; Aspinall, E.J.; Goldberg, D.J.; Barclay, S.T.; Dillon, J.F.; Fox, R.; Fraser, A.; et al. Hepatitis C reinfection following treatment induced viral clearance among people who have injected drugs. Drug Alcohol. Depend. 2016, 165, 53-60. [CrossRef] [PubMed]

19. Martinello, M.; Grebely, J.; Petoumenos, K.; Gane, E.; Hellard, M.; Shaw, D.; Sasadeusz, J.; Applegate, T.L.; Dore, G.J.; Matthews, G.V. HCV reinfection incidence among individuals treated for recent infection. J. Viral. Hepat. 2017, 24, 359-370. [CrossRef] [PubMed]

20. Grebely, J.; Pham, S.T.; Mattews, G.V.; Petoumenos, K.; Bull, R.A.; Yeung, B.; Rawlinson, W.; Kaldor, J.; Lloyd, A.; Hellard, M.; et al. Hepatitis $C$ virus reinfection and superinfection among treated and untreated participants with recent infection. Hepatology 2012, 55, 1058-1069. [CrossRef] [PubMed]

21. Aspinall, E.J.; Corson, S.; Doyle, J.S.; Grebely, J.; Hutchinson, S.J.; Dore, G.J.; Goldberg, D.J.; Hellard, M.E. Treatment of hepatitis C virus infection among people who are actively injecting drugs: A systematic review and meta-analysis. Clin. Infect. Dis. 2013, 57, S80-S89. [CrossRef]

22. Dore, G.J.; Altice, F.; Litwin, A.H.; Dalgard, O.; Gane, E.J.; Shibolet, O.; Luetkemeyer, A.; Nahass, R.; Peng, C.-Y.; Conway, B.; et al. Elbasvir-grazoprevir to treat hepatitis $C$ virus infection in persons receiving opioid agonist therapy. Ann. Intern. Med. 2016, 165, 625-634. [CrossRef] [PubMed]

23. Simmons, B.; Saleem, J.; Hill, A.; Riley, R.D.; Cooke, G.S. Risk of late relapse or reinfection with hepatitis C virus after achieving a sustained virological response: A systematic review and meta-analysis. Clin. Infect. Dis. 2016, 62, 683-694. [CrossRef] [PubMed]

24. Pabjan, P.; Brzdek, M.; Chrapek, M.; Dziedzic, K.; Dobrowolsa, K.; Pauch, K.; Garbat, A.; Blonarczyk, P.; Reczko, K.; Stepien, P.; et al. Are There Still Difficult-to-Treat Patients with Chronic Hepatitis C in the Era of Direct-Acting Antivirals? Viruses 2022, 14, 96. [CrossRef] [PubMed]

25. Ingiliz, P.; mARTIN, T.C.; rODGER, A.; Stellrink, H.-J.; Mauss, S.; Boesecke, C.; Mandorfer, M.; Bottero, J.; Baumgarten, A.; Bhagani, S.; et al. HCV reinfection incidence and spontaneous clearance rates in HIV-positive men who have sex with men in Western Europe. J. Hepatol. 2017, 66, 282-287. [CrossRef] [PubMed]

26. Daskalopoulou, M.; Rodger, A.; Phillips, A.N.; Sherr, L.; Speakman, A.; Collins, S.; Elford, J.; Johnson, M.A.; Gilson, R.; Fisher, M.; et al. Recreational drug use, polydrug use, and sexual behaviour in HIV-diagnosed men who have sex with men in the UK: Results from the cross-sectional ASTRA study. Lancet HIV 2014, 1, e22-e31. [CrossRef]

27. Guideline for the Use of Pre-Exposure Oral Prophylaxis (PrEP) in Taiwan. Available online: http://www.aids-care.org.tw/DB/ News / file/254-1.pdf (accessed on 2 May 2016). 